\title{
Social Media and Non-Personal Communication for Increasing Brand Equity and Their Implications towards Customer Value
}

DOI: https://doi.org/10.47175/rissj.v3i1.384

\author{
| Taufik Zulfikar ${ }^{1, *}$ | Adhi Al Hadi Haqq ${ }^{2}$ | Didin Saepudin ${ }^{3}$ | \\ 1,3Lecturer, Magister \\ Management, Sangga Buana \\ University, Bandung, Indonesia \\ ${ }^{2}$ Student, Magister \\ Management, Sangga Buana \\ University, Bandung, Indonesia. \\ ${ }^{1}$ taufikzulfikar16@gmail.com \\ ${ }^{2}$ adhi.alhadi@gmail.com \\ ${ }^{3}$ Didinsaepudin.250366@gmail.con

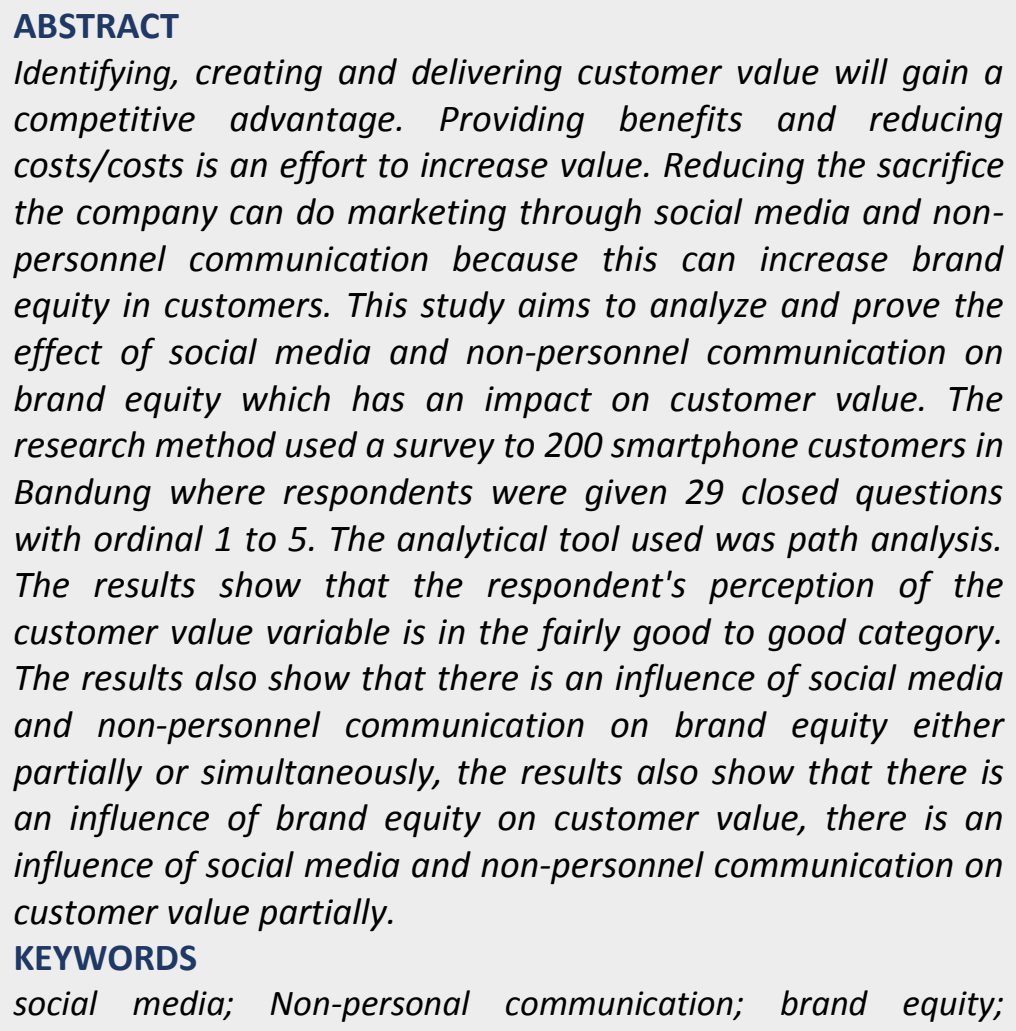

\section{INTRODUCTION}

Identifying, creating, and delivering value towards customers are company strategies to gain competitive advantage. Competition is a relationship moderator between customer value and loyalty from a customer's perspective. Moreover, competition is a customer loyalty predictor from the employee's perspective (Shu Ching Chen, 2015). Companies able to give more values to their customers will gain competitive advantage. A study conducted by Farida \& Kusuma, (2017) showed that there was a positive impact and a significant service quality and market mix on customer value (social, emotional, performance and price values) and competitive advantage and customer value can mediate the impact of service quality and market mix for competitive advantage. The product differentiation has a positive and significant effect on competitive advantage, and customer value has a positive and significant impact on competitive advantage (Mujahida et al., 2018)

Customer value can be created by using several strategies including providing numerous benefits by reducing sacrifice from customers (Martín-Ruiz et al., 2012). The total benefit consists of utility value and psychological value, while customer sacrifice consists of customer cost either financially or non financially (Khalifa, 2004). The source of superior customer value can be obtained from the resource and organisation's capability such as 
management, human resources, innovation, and the culture and the structure of the organization (Nasution \& Mavondo, 2008). Customer value includes product quality and service. Providing optimal service is an appropriate strategy for successful business operations, because retaining customers is cheaper than gathering new customers (Donny et al., 2018). One of the ways to provide optimal benefits is to give information on a product or service to customers. Social media and non-personal communications are facilities used to inform products and services. Social media is used because it has time, audience, relation, and cost advantages. Costs can be reduced through social media because the required distribution part in mass media is omitted. Most of the social media is accessed without any cost (Kirtiş \& Karahan, 2011) Communication can also reduce cost for both customers and companies (Bilal et al., 2013). Initially, mass media advertisements are considered appropriate and useful. However, currently experts consider them ineffective due to the high cost and unpredictable targets. Now, in order to achieve the right target, companies use promotional techniques like direct mail and cable TV (Brunello, 2013). Communication can also create brand equity. Several studies connecting communication and brand equity among others (Wardhana \& Rustandi Kartawinata, 2013), on the relationship between integrated marketing communication, (Diab \& Mansour, 2019), the relationship between personnel communication and brand equity, (Murtiasih et al., 2013) on the relationship between WoM and brand equity, and (Grubor et al., 2017) on the relationship between social media and brand equity. This study will study the impact of social media and non-personal communication on brand equity and its implication on customer value, with the respondents

\section{LITERATURE REVIEW}

\section{The Relationship between Social Media and Brand Equity}

Social media can increase brand equity in customers (Grubor et al., 2017). The use of social media can increase brand awareness (Stojanovic et al., 2018). Social media, in this case Instagram, can increase brand awareness, brand association, and brand loyalty (Tresna \& Wijaya, 2015; Mahnoor Mazhar, 2018). Social media marketing with the dimensions of consumption, curation, creation, and collaboration has impacts on brand equity (Hutagalung \& Situmorang, 2018).

H1 : The impact of social media and non-personal communication on brand equity $H 2$ : The impact of social media on brand equity

\section{The Relationship between Non-Personal Communication with Brand Equity}

Integrated marketing communication with a non-personal communication dimension can influence brand equity (Wardhana \& Rustandi Kartawinata, 2013). Advertising, corporate reputation, and price promotion can influence brand equity (Mubushar, M., Haider, I., \& Iftikhar, 2013). IMC tools can have implications towards brand equity (Irfan Shafi \& Madhavaiah, 2013). IMC has a significant value to give contribution towards customer perceptions on company brand equity (Brunello, 2013).

H3: The impact of personal communication on brand equity

\section{The Relationship between Brand Equity and Customer Value}

The implementation of brand innovation, mediated by brand equity, provides significant, specific, and indirect influence on the company's customer value (Chien, 2013). The concept of brand awareness and price fairness is found to play a role in the processing of 
customer value (Hanzaee \& Yazd, 2010). Brand awareness and brand class have influence towards perceived value (Oh, 2000).

$H 4$ : The impact of brand equity on customer value

\section{The relationship between Social Media and Customer Value}

Social media is used because it has time, audience, relation, and cost advantages. Costs can be reduced through social media because the required distribution part in mass media is omitted. Most of the social media is accessed without any cost (Kirtiş \& Karahan, 2011). The analysis result indicated that social media marketing activities indirectly influence satisfaction mediated by social identification and perceived value (Shih Chih Chen \& Lin, 2019). The development of target groups and issue-by-issue advertising and promotion are available at a lower cost (Lee, 2010). Social media in itself does not produce customer value, but it must also be accompanied with connection and interaction between the company and its customers, and among the customers themselves (Li et al., 2021).

H5: The impact of social media and non-personal communication on customer value H6 : The impact of social media on customer value

\section{The Relationship between Non-Personal Communication and Customer Value}

Etiquette-based marketing communication through customer value can describe the influence on customer loyalty variables (Nurdin, 2012). To exceed customer satisfaction and not just meet it, companies must emphasize communication to identify consumer needs and getting feedback on existing and potential new products (Nwabueze \& Mileski, 2018). Not only is competitive advantage aimed at what is being produced, but also at what is being added to the product in the form of advertisements, package, advice directed to customers, and everything customers appreciate. Moreover, public relations and advertisements are considered as key communication elements in modern organisations, because they connect organization not only with customers but also with the public and stakeholders in many ways (Miletic, 2010).

H7: The impact of non-personal communication on customer value

\section{RESEARCH METHODS}

The study method used is a quantitative method with a descriptive verificative as the analytical method. The survey used for data collection method is gathered through distributing questionaires raising 29 enclosed questions with the scale from 1 to 5 . The number of respondents in this study was 200 people who are smartphone users in Bandung, with the sample collection technique using the isidental probability sampling. The data of the respondents data are presented in table 1.

Table 1. Respondent profile

\begin{tabular}{llcc}
\hline Demographic profile & Category & Frequency & Percent \\
\hline Gender & Male & 86 & 43 \\
& Female & 114 & 57 \\
\hline Age & 2 20 years & 54 & 27 \\
& $21-30$ years & 87 & 44 \\
& $31-40$ years & 25 & 12 \\
& $41-50$ years & 18 & 9 \\
& $>$ 50 years & 16 & 8 \\
\hline Profession & Students & 65 & 32 \\
& Employees & 60 & 30 \\
\hline
\end{tabular}




\begin{tabular}{llcc}
\hline Demographic profile & Category & Frequency & Percent \\
\hline & Government Employees & 23 & 13 \\
& Entrepreneurs & 20 & 10 \\
& Others & 30 & 15 \\
\hline
\end{tabular}

Path analysis is used as the analytical tool. The structural model of the study is as follows:

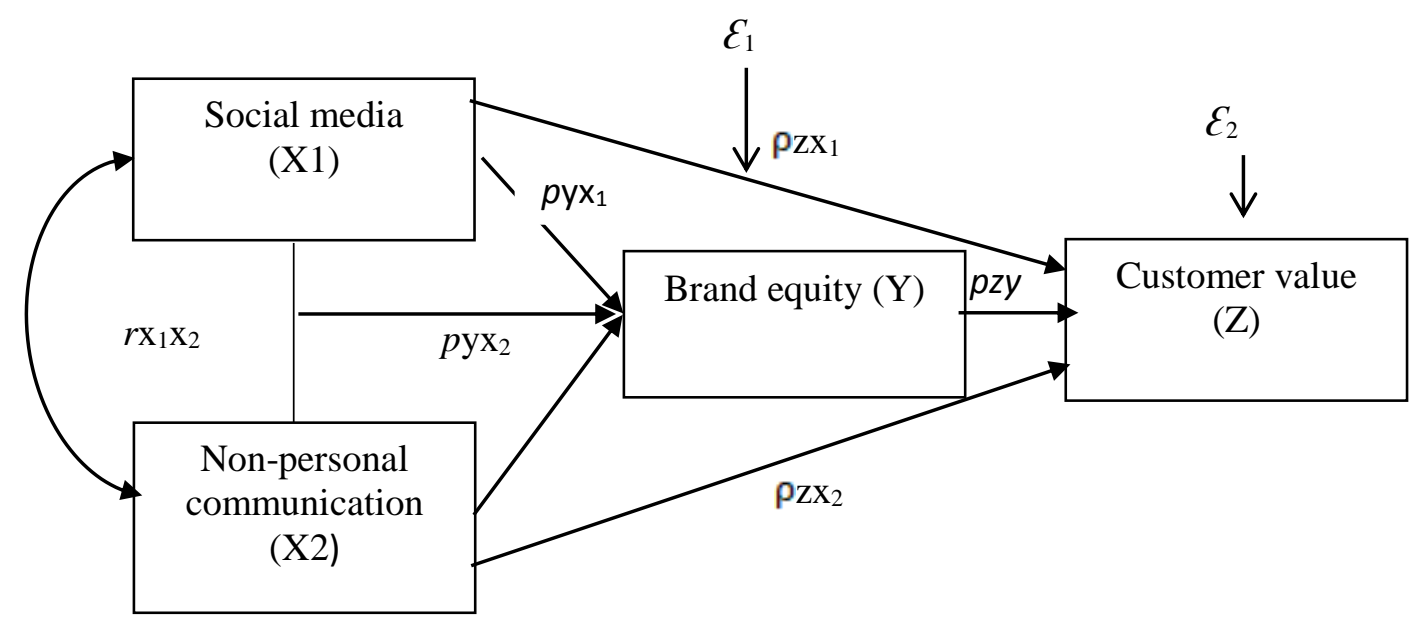

Figure 1. The diagram of the study path

The research model consists of three sub structures:

1. The first path equation:

$$
Y=p y X 1+p y X 2+\varepsilon
$$

2. The second path equation:

$$
z=p z Y+\varepsilon_{2}
$$

3. The third path equation:

$$
Z=p z X 1 \cdot X 1+p z X 2 \cdot X 2+p z y
$$

\section{RESULTS AND DISCUSSION}

\section{Validity Test, Reliability Test, and Normality Test}

The level of significance in this test is $5 \%$. The result of validity test in this study shows that the question points are stated to be valid because $r$ count is greater than $r$ table $(0.30)$. The reliability test was done by using Cronbach's Alpha indicator. The test result shows the Cronbach's Alpha value of the four variables in this study is $>0.6$ so the three variables are stated to be reliable.

\section{Respondent's Response}

The perception of respondents towards social media variable in average is under the "fairly good" category to "good" with the average score of 3.43, where the highest score is on the level of interest indicator, which is 3.89 , which belongs to the "good" category and the lowest score is on the participation level indicator with a score of 3.19 and followed by forum contribution level with a score of 3.22. The respondent's perception towards nonpersonal communication lies under the "fairly good category" with a score of 3.71, where the highest score is on the level of advertisement interest indicator with a score of 3.88, belonging to the "good" category and the lowest score is on the given promotion 
frequency, with a score of 3.44 , which belongs to the "good" category followed by promotion variation with a score of 3.57. The respondent's perception on brand equity variable is in the "good" to "very good" category with an average score of 3.01, where the highest score is on the brand name indicator with a score of 4.24, which belongs to the "very good" category. Meanwhile the lowest score is in the recommendation level indicator with a score of 3.56, which belongs to the "good" category and followed by repeat purchase with a score of 3.72 in the "good" category. The respondent's perception towards the customer value variable falls under the "fairly good" to "good" category with an average score of 3.75. The highest score is on the ease of purchase with a score of 4.25 , which belongs to the "good" category and followed by price affordability with a score of 4.18 , which belongs to the "good" category. While the lowest score is on the service quality level indicator with a score of 3.53, which belongs to the "good" category, followed by the product and price compatibility level with a score of 3.64, which is in the "good" category.

Table 2. Normality test result

\begin{tabular}{|ll|r|}
\hline & & Unstandarized Residual \\
\hline $\mathrm{N}$ & & 200 \\
Normal Parameter & Mean & .000000 \\
& Std. Deviation & 3.71714389 \\
Most Extreme Differences & .058 \\
& Absolute & .054 \\
& Positive &. .058 \\
Kolmogorov-Smirnov Z & Negative & .819 \\
Asymp.Sig (2-tailed) & & .513 \\
\hline
\end{tabular}

The regression model can be assumed as "good" if the distribution is normal or close to normal. The significance obtained from the Kolmogorov-Smirnov test is $0.513>0.05$, if the significance result is greather than 0.05 , The conclusion will be that the data is normally distributed. The results of the test will determine the normality of the data through the Kolmogorov-Smirnov test using SPSS.

\section{Path Analysis}

\section{Substructure 1}

Path analysis was taken to find out the impact of social media and non-personal communication on brand equity and to find out the impact of social media and nonpersonal communication on customer value. The complete path analysis is presented as follows:

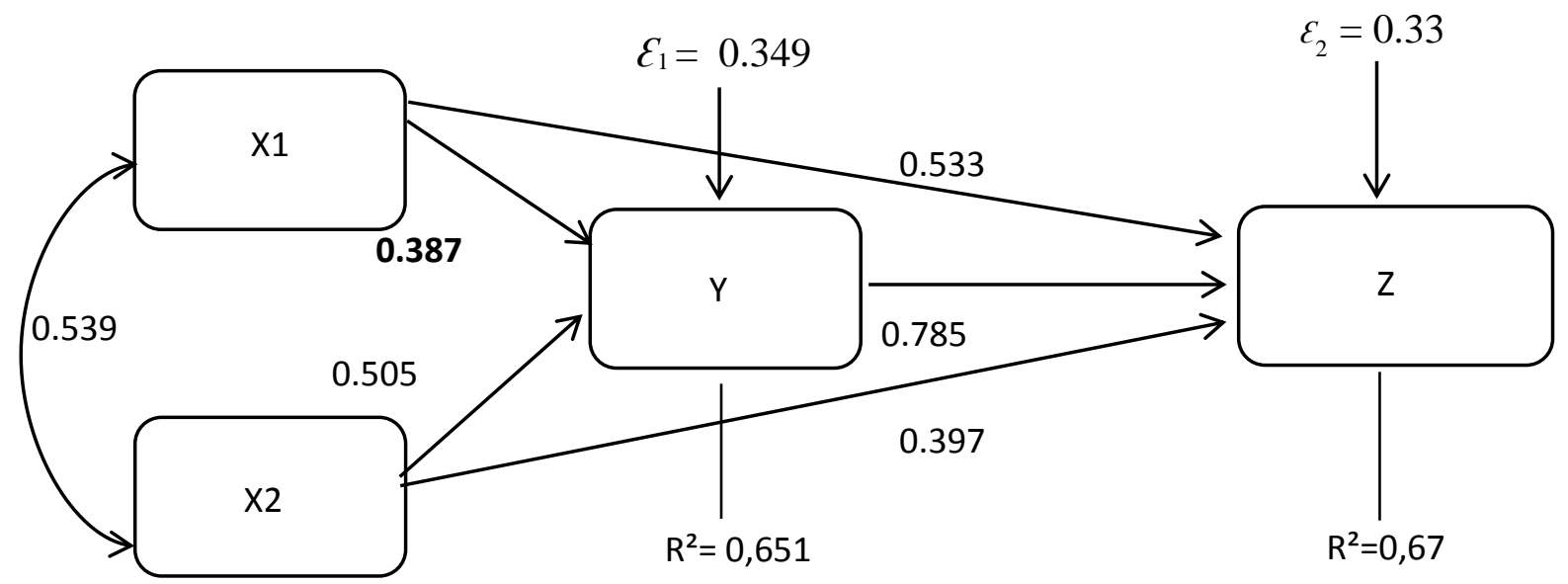

Figure 2. The diagram of Path of $\mathrm{X} 1, \mathrm{X} 2$, and $\mathrm{Y}$ towards $\mathrm{Z}$ 
The correlation value between the social media variable and the non-personal communication variable is 0.539 and categorized as a fairly strong correlation.

Table 3. The correlation between social media and non-personal communication

\begin{tabular}{|ll|r|r|}
\hline & VAR00001 & VAR00002 \\
\hline VAR00001 & Pearson Correlation & 1 & .539 \\
& Sig. (2-tailed) & & .000 \\
$\mathrm{~N}$ & 200 & 200 \\
\hline VAR00001 & Pearson Correlation & .539 & 1 \\
& Sig. (2tailed) & 000 & \\
$\mathrm{~N}$ & 200 & 200 \\
\hline
\end{tabular}

The coefficient value of social media to brand equity path is 0.387 . The coefficient value of non-personal communication to the brand equity path is 0.505 .

Table 4. The Path Coefficient of substructure 1

\begin{tabular}{|l|r|r|r|r|r|}
\hline \multirow{2}{*}{ Model } & \multicolumn{2}{|c|}{$\begin{array}{c}\text { Unstandardized } \\
\text { Coefisinets }\end{array}$} & $\begin{array}{l}\text { Standardized } \\
\text { Coefisinets }\end{array}$ & \multirow{2}{*}{$\mathrm{t}$} & \multirow{2}{*}{ Sig } \\
\cline { 2 - 5 } & \multicolumn{1}{|c|}{ B } & \multicolumn{1}{c|}{ Std. Error } & \multicolumn{1}{c|}{ Beta } & & \\
\hline 1. (Constant) & .559 & 1.605 & & 348 & .728 \\
Social Media & .851 & .115 & .387 & 7.378 & .000 \\
Non-personal & .734 & .076 & .505 & 9.634 & .000 \\
Communication & & & & & \\
\hline
\end{tabular}

The Determination Coefficient value of substructure 1 as presented on table 5 is 0.651 .

Table 5. The Path determination coefficient value of substructure 1

\begin{tabular}{|c|r|r|r|r|}
\hline Model & R & R Square & Adjusted R Square & $\begin{array}{c}\text { Std. Error of The } \\
\text { Estimate }\end{array}$ \\
\hline 1 & .806 & .651 & .649 & 3.73596 \\
\hline
\end{tabular}

Using the information on table 4 and table 5 as previously described, the researcher could present the path analysis diagram on figure 3 below:

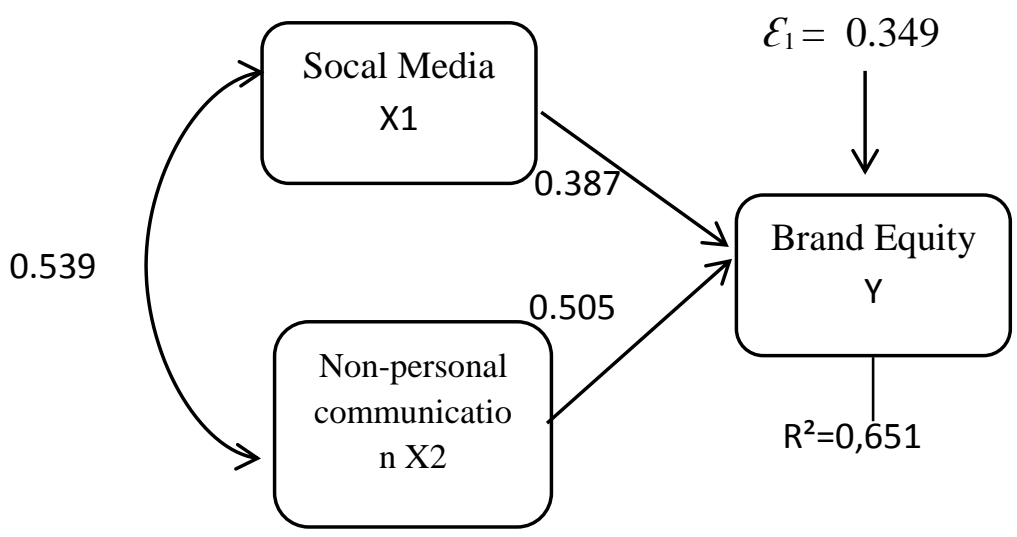

Figure 3. Diagram of Substructure 1

According to figure 4, the researcher made a structural equation as follows:

$$
\mathrm{Y}=0,387 \mathrm{X}_{1}+0,505 \mathrm{X}_{2}+\varepsilon_{1}
$$


Hypothesis test 1: Social media and non-personal communication on brand equity simultaneously

In table 6 , the significance value shows 0.00 where the result is below the determined maximum standard error, which is $5 \%$ or $0.00<0.05$. Therefore, it can be concluded that social media and non-personal communication simultaneously have a significant impact on brand equity

Table 6. Hypothesis test 1

\begin{tabular}{|l|r|r|r|r|r|}
\hline Model & \multicolumn{1}{|c|}{$\begin{array}{c}\text { Sum of } \\
\text { Squares }\end{array}$} & \multicolumn{1}{c|}{ df } & \multicolumn{1}{c|}{$\begin{array}{c}\text { Mean } \\
\text { Square }\end{array}$} & F & Sig \\
\hline 1. Regression & 4401.144 & 2 & 2200.572 & 157.663 & .000 \\
Residual & 2749.615 & 197 & 13.957 & & \\
Total & 7150.759 & 199 & & & \\
\hline
\end{tabular}

Hypothesis test 2: Social media on brand equity

Based on table 4 , the significance value shown by the social media variable is 0.00 where the result is below the error standard of $5 \%$ or $0.00<0.05$. This shows that social media has a significant impact on brand equity.

\section{Hypothesis test 3: Non-personal communication on brand equity}

Based on table 4, the significance value shown by the non-personal communication variable is 0.00 , where the result is below the error standard of $5 \%$ or $0.00<0.05$. This shows that non-personal communication has a significant impact on brand equity.

\section{Substructure 2}

Path coefficient

Based on table 7, the coefficient value of brand equity path $(\mathrm{Y})$ on customer value $(\mathrm{Z})$ is 0.785

Table 7. Coefficient of substructure 2

\begin{tabular}{|l|r|r|r|r|r|}
\hline \multirow{2}{*}{ Model } & \multicolumn{2}{|c|}{$\begin{array}{c}\text { Unstandardized } \\
\text { Coefisinets }\end{array}$} & $\begin{array}{l}\text { Standardized } \\
\text { Coefisinets }\end{array}$ & \multirow{2}{*}{$\mathrm{t}$} & \multirow{2}{*}{ Sig } \\
\cline { 2 - 5 } & \multicolumn{1}{|c|}{ B } & \multicolumn{1}{c|}{ Std. Error } & \multicolumn{1}{c|}{ Beta } & & \\
\hline 1. (Constant) & 8.768 & .961 & & 9.119 & .000 \\
Brand Equity & .599 & .034 & .785 & 17.850 & .000 \\
\hline
\end{tabular}

\section{Determination Coefficient of Substructure 2}

The substructure 2 determination coefficient value can be seen in the R square column of the Linear Regression Equation of the impact of brand equity on customer value. The result is presented in table 8 .

Table 8. Substructure 2 determination coefficient

\begin{tabular}{|c|r|r|r|r|}
\hline Model & \multicolumn{1}{|c|}{ R } & R Square & $\begin{array}{c}\text { Adjusted R } \\
\text { Square }\end{array}$ & $\begin{array}{r}\text { Std. Error of } \\
\text { The Estimate }\end{array}$ \\
\hline 1 & .785 & .617 & .615 & 2.83905 \\
\hline
\end{tabular}

Based on data where the path coefficient value is 0.391 and the determination coefficient value is 0.617 or $61.7 \%$, the researcher made a sub structure 2 path analysis figure as presented in figure 4 . 


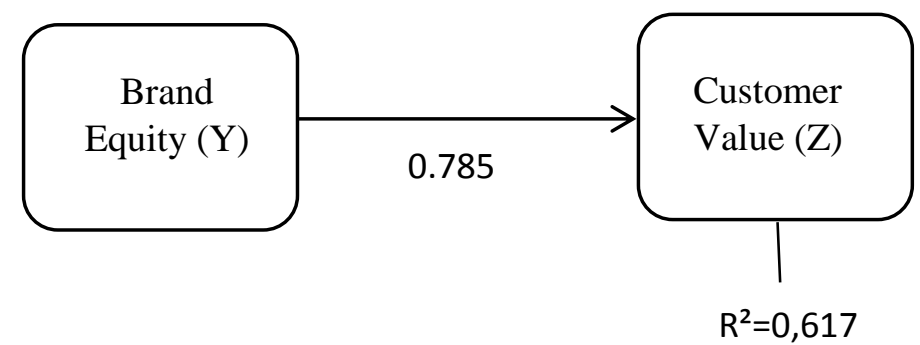

Figure 4. Substructure 2

The researcher used the data from figure 4. to make a substructure 2 equation as follows:

$$
\mathrm{Z}=0,785 \mathrm{Y}+\varepsilon_{2}
$$

Hypothesis test 4: Brand equity on customer value

Table 9. Hypothesis test 4

\begin{tabular}{|l|r|r|r|r|r|}
\hline Model & \multicolumn{1}{|c|}{$\begin{array}{c}\text { Sum of } \\
\text { Squares }\end{array}$} & \multicolumn{1}{c|}{ df } & \multicolumn{1}{c|}{$\begin{array}{c}\text { Mean } \\
\text { Square }\end{array}$} & F & Sig \\
\hline 1. Regression & 2568.046 & 1 & 2568.046 & 318.607 & .000 \\
Residual & 1595.926 & 198 & 8.060 & & \\
Total & 4163.972 & 199 & & & \\
\hline
\end{tabular}

In table 9, the significance value shows 0.00 where the result is below the determined maximum error standard, which is $5 \%$ or $0.00<0.05$. Therefore, it can be concluded that brand equity has a significant impact on customer value,

\section{Substructure 3}

Path coefficient

Based on table 10, the coefficient values of social media and non-personal communication on customer value are 0.544 and 0.397 respectively.

Table 10. The path coefficient of Substructure 3

\begin{tabular}{|l|r|r|r|r|r|}
\hline \multirow{2}{*}{ Model } & \multicolumn{2}{|c|}{$\begin{array}{c}\text { Unstandardized } \\
\text { Coefisinets }\end{array}$} & $\begin{array}{l}\text { Standardized } \\
\text { Coefisinets }\end{array}$ & \multirow{2}{*}{$\mathrm{t}$} & \multirow{2}{*}{ Sig } \\
\cline { 2 - 4 } & \multicolumn{1}{|c|}{$\mathrm{B}$} & \multicolumn{1}{c|}{ Std. Error } & \multicolumn{1}{c|}{ Beta } & & \\
\hline 1. (Constant) & 4.684 & 1.134 & & 4.129 & .000 \\
Social Media & .895 & .082 & .533 & 10.982 & .000 \\
Non-personal & .440 & .054 & .397 & 8.178 & .000 \\
Communication & & & & & \\
\hline
\end{tabular}

\section{Substructure 3 Determination Coefficient}

Table 11. The Determination Coefficient of Substructure 3

\begin{tabular}{|c|r|r|r|r|}
\hline Model & R & R Square & $\begin{array}{c}\text { Adjusted R } \\
\text { Square }\end{array}$ & $\begin{array}{c}\text { Std. Error of } \\
\text { The Estimate }\end{array}$ \\
\hline 1 & .819 & .670 & .667 & 2.64013 \\
\hline
\end{tabular}

Using the correlation value of 0.785 , the path coefficient values of 0.533 and 0.397 , and determination coefficient value of 0.67 , the researcher made a Substructure 3 path analysis figure as shown in figure 5 . Based on figure 5 the researcher made a structural equation as follows: 


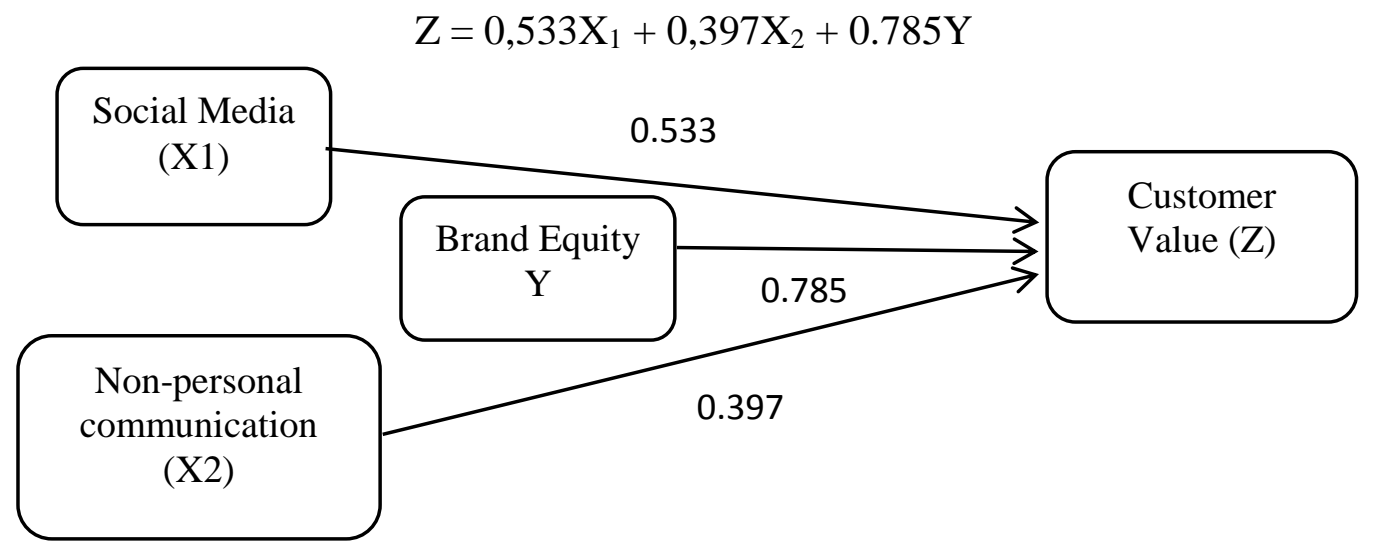

Figure 5. The Path Diagram of Substructure 3

Hypothesis test 5: Simultaneous Social media and non-personal communication on customer value

Table 12. Hypothesis 5 test

\begin{tabular}{|l|r|r|r|r|c|}
\hline Model & Sum of Squares & \multicolumn{1}{c|}{ df } & Mean Square & \multicolumn{1}{c|}{ F } & Sig \\
\hline 1. Regression & 2790.823 & 2 & 1395.411 & 200.194 & .000 \\
Residual & 1373.149 & 197 & 6.970 & & \\
Total & 4163.972 & 199 & & & \\
\hline
\end{tabular}

In table 12, the significance value shows 0.00 where the result is below the determined maximum error standard, which is $5 \%$ or $0.00<0.05$. Therefore, it can be concluded that social media and non-personal communication simultaneously has an impact on customer value

Hypothesis test 6: Social media on customer value

In table 10 , the significance value shown by the social media variable is 0.00 , where the result is below the error standard of $5 \%$ or $0.00<0.05$. This shows that social media has a significant impact on customer value.

Hypothesis test 7: Non-personal communication on customer value

In table 12 , the significance value shown by the social media variable is 0.00 , where the result is below the error standard of $5 \%$ or $0.00<0.05$. This shows that non-personal communication has a significant impact on customer value.

\section{CONCLUSION}

The analytical data show that social media and non-personal communication affect brand equity whether partially or simultaneously which has implications for customer value. The result also shows that social media and non-personal communication affects customer value.

\section{REFERENCES}

Bilal, M., Saeed, R., Naeem, B., \& Naz, U. (2013). Integrated Marketing Communication :

A Review Paper. Interdisciplinary Journal of Contemporary Research in Business, 5 (5)(September), 124-133.

Brunello, A. (2013). The Relationship Between Integrated Marketing Communication and 
Brand Equity. International Journal of Communication Research, 3(1), 9-14.

Chen, Shih Chih, \& Lin, C. P. (2019). Understanding the effect of social media marketing activities: The mediation of social identification, perceived value, and satisfaction. Technological Forecasting and Social Change, 140(July 2018), 22-32. https://doi.org/10.1016/j.techfore.2018.11.025

Chen, Shu Ching. (2015). Customer value and customer loyalty: Is competition a missing link? Journal of Retailing and Consumer Services, 22(July), 107-116. https://doi.org/10.1016/j.jretconser.2014.10.007

Chien, Y.-C. (2013). The Influences of Brand Innovation on Customer Value: Using Double-Distal Mediators of Brand Perception and Brand Equity. Journal of Global Business Management, 9(2), 53-70. search.proquest.com.pugwash.lib.warwick.ac.uk/docview/1441253941 ?accountid=14 888\%0Ahttp://webcat.warwick.ac.uk:4550/resserv??genre=article\&issn=18173179\&t itle $=$ Journal+of+Global+Business+Management $\&$ volume $=9 \&$ issue $=2 \&$ date $=2013$ 06-01\&atitle=The+Influ

Diab, D., \& Mansour, I. H. F. (2019). The Impact of Marketing Efforts on Brand Equity: A Case of Samsung Brand in Sudan. SSRN Electronic Journal, 16(2), 1-13. https://doi.org/10.2139/ssrn.2613829

Donny, J. R., Juju, U., Jusuf, E., \& Rosmadi, M. L. N. (2018). The Factors That Affect Customer Value and Its Impact on the Customer Loyalty. Budapest International Research and Critics Institute (BIRCI-Journal): Humanities and Social Sciences, 1(4), 299-305. https://doi.org/10.33258/birci.v1i4.122

Farida, L., \& Kusuma, A. A. (2017). Revitalizing Customer Value And Competitive Advantage Of Coastal Culinary Tourism In Jember. International Journal of Scientific \& Technology Research, 6(12), 154-160.

Grubor, A., Djokic, I., \& Milovanov, O. (2017). The influence of social media communication on brand equity: The evidence for environmentally friendly products. Applied Ecology and Environmental Research, 15(3), 963-983. https://doi.org/10.15666/aeer/1503_963983

Hanzaee, K., \& Yazd, R. M. (2010). The impact of brand class, brand awareness and price.pdf. African Journal of Business Management, 4(17), 3775-3784.

Hutagalung, B., \& Situmorang, S. H. (2018). The Effect Of Social Media Marketing On Value Equity, Brand Equity And Relationship Equity On Young Entrepreneurs In Medan City. Advance in Economic, Business and Management Research (AEBMR), 46(Ebic 2017), 534-540. https://doi.org/10.2991/ebic-17.2018.84

Irfan Shafi, S., \& Madhavaiah, C. (2013). Role of Integrated Marketing Communications in Building Brand Equity: A Review and Research Agenda. Amity Business Review, 14(No. 2, July).

Khalifa, A. S. (2004). Customer value: a review of recent literature and an integrative configuratio. In Management Decision (Vol. 42, Issue 5). https://doi.org/http://dx.doi.org/10.1108/MRR-09-2015-0216

Kirtiş, A. K., \& Karahan, F. (2011). To Be or not to Be in social media arena as the most cost-efficient marketing strategy after the global recession. Procedia - Social and Behavioral Sciences, 24, 260-268. https://doi.org/10.1016/j.sbspro.2011.09.083

Lee, D.-H. (2010). Growing Popularity of Social Media and Business Strategy. SERI Quarterly, $3(4)$, $112-117$. http://search.ebscohost.com/login.aspx?direct=true \&db=bth\&AN=54425537\&lang=pt -br\&site=ehost-live

Li, F., Larimo, J., \& Leonidou, L. C. (2021). Social media marketing strategy: definition, 
conceptualization, taxonomy, validation, and future agenda. Journal of the Academy of Marketing Science, 49(1), 51-70. https://doi.org/10.1007/s11747-020-00733-3

Mahnoor Mazhar, 01-222162-020. (2018). The impact of Social Media Communication on Brand Awareness, Brand Equity and Purchase Intention: A study of Apparel Brands in Pakistan. 3(2), 204-213.

Martín-Ruiz, D., Barroso-Castro, C., \& Rosa-Díaz, I. M. (2012). Creating Customer Value Through Service Experiences: an Empirical Study in the Hotel Industry. Tourism and Hospitality Management, 18(1), 37-53. http://search.proquest.com/docview/1026947682?accountid=14495\%5Cnhttp://diana. uca.es:4550/resserv?genre $=$ article $\&$ issn $=13307533 \&$ title $=$ Tourism + and + Hospitality + Management $\&$ volume $=18 \&$ issue $=1 \&$ date $=2012-05$ -

01\&atitle $=$ CREATING+CUSTOMER+VALUE+THROUGH+SERVICE+EXPERIE

Miletic, S. (2010). IMAGE COMMUNICATION AND COMPETITIVE ADVANTAGE. Economics and Organization, 7(1), 119-128.

Mubushar, M., Haider, I., \& Iftikhar, K. (2013). The effect of integrated marketing communication on customer based brand equity with mediating role of corporate reputation in cellular industry of Pakistan. Global Journal of Management and Business Research Marketing, 13(6),(6), 21-29.

Mujahida, S., Brasit, A., Maupa, H., \& Pono, M. (2018). Influence of The Differentation of Products and Customer Value Against Competing Superiority on Businesss Franchise In The City of Makassar. International Journal of Innovative Science and Research Technology, 3(7).

Murtiasih, S., Sucherly, \& Siringoringo, H. (2013). How Word of Mouth Influence Brand Equity for Automotive Products in Indonesia. Procedia - Social and Behavioral Sciences, 81, 40-44. https://doi.org/10.1016/j.sbspro.2013.06.384

Nasution, H. N., \& Mavondo, F. T. (2008). Customer value in the hotel industry: What managers believe they deliver and what customer experience. International Journal of Hospitality Management, 27(2), 204-213. https://doi.org/10.1016/j.ijhm.2007.02.003

Nurdin, A. (2012). Pengaruh Komunikasi Pemasaran Terpadu Berbasis Etika Dalam Menciptakan Nilai Pelanggan Dan Implikasinya Terhadap Loyalitas Pelanggan Susu Formula Bayi Di Indonesia. Indonesian Journal of Economics and Business, 2(1), 1-2.

Nwabueze, U., \& Mileski, J. (2018). Achieving competitive advantage through effective communication in a global environment. Journal of International Studies, 11(1), 50 66. https://doi.org/10.14254/2071-8330.2018/11-1/4

Oh, H. (2000). The Effect of Brand Class, Brand Awareness, and Price on Customer Value and Behavioral Intentions. Journal of Hospitality and Tourism Research, 24(2), 136162. https://doi.org/10.1177/109634800002400202

Stojanovic, I., Andreu, L., \& Curras-Perez, R. (2018). Effects of the intensity of use of social media on brand equity: An empirical study in a tourist destination. European Journal of Management and Business Economics, 27(1), 83-100. https://doi.org/10.1108/EJMBE-11-2017-0049

Tresna, L., \& Wijaya, J. C. (2015). The Impact of Social Media Towards Brand Equity: An Empirical Study of Mall X. IBuss Management, 3(2), 37-48.

Wardhana, A., \& Rustandi Kartawinata, B. (2013). The Effects of Integrated Marketing Communicationson Brand Equity of Authorized Automotives Companies in Indonesia. International Journal of Science and Research, 4(4), 2319-7064. www.ijsr.net 